\title{
ETHICS AND WORKING CULTURE OF THE EMPLOYEES IN THE REGION MUNICIPALITY
}

\author{
Dalia Perkumiené ${ }^{1}$, Rasa Merkienè $\dot{1}^{1}$, Biruta Švagždiené ${ }^{2}$ \\ Aleksandras Stulginskis University ${ }^{1}$, Kaunas, Lithuania \\ Lithuanian Sports University ${ }^{2}$, Kaunas, Lithuania
}

\section{ANOTATION}

Culture - the informal aspects of organizations - are the values, beliefs, ethics, and motives of individual participants in addition to the shared norms and understanding that broadly characterize the organization or its subunits.

The article analyses peculiarities of ethics and working culture in public sector. The authors try to reveal and evaluate the specialities of ethics and working culture of the Klaipeda municipality employees.

Conflicts in the work of public sector officers are the negative appearance because of their negative impact on the person itself and the people around - customers, colleagues. It has negative impact on the efficiency of work, communication, working atmosphere.

Keywords: working culture, ethics, employees, public sector.

\section{INTRODUCTION}

Ethics covers various areas of life: personal, public and professional relations. Personal ethics studies the well-being of certain individual and his development methods. Social ethics emphasizes the well-being of the society, duties of individual persons in the society. In the professional ethics much attention is paid to the behaviour of the representatives of special field (Raipa, 2001).

Employees working in public sector inevitably stuck with ethics and working culture problems. Perhaps even more often than the representatives of other fields because they are constantly communicating with people, help them to solve their problems every day, inform people about new products (Wagner-Tsukamoto, 2005).

When having some contact with employees, people judge the morality and working culture of higher officers and all sector according to their behaviour (Chen, 2005). Therefore ethics and working culture of public sector employees should be as high as possible. Ethics is important not only in communication with customers (external environment) but also internally in the organization, in the mutual relations between colleagues and staff members (Palidauskaite, 2001).

Ethical problems might cause various consequences. Some of them are solved almost unnoticed; the others have strong impact on separate persons or organizations. Ethical problems might occur and disappear or have continuous character.

The purpose of the work was to disclose the importance of ethics and working culture of the employees in the Klaipeda municipality sector.

Object of the work was ethics and working culture of the employees.

Materials and methods of the work. In this paper there we used analysis of scientific literature, analysis of legislation, survey with questionnaire, statistical analysis of the data, graphical modelling, and specifying, summarizing and logical abstraction methods. We also analysed 
scientific and practical materials of national and foreign authors (Raipa, Palidauskaite, Chen, Fassin and others). In order to disclose the importance of ethics and working culture of the employees we have chosen the municipality of Klaipeda region for the research.

\section{RESULTS}

In our everyday life we use notions of ethics, morality, virtue and others quite widely. However, not always we think about their content and significance. Sometimes we refer to these notions in wrong places, very often we identify them, use them as synonyms. However we should not confuse these notions and separate them: ethics is a field of certain knowledge, science; morality and virtue are its research subjects (Kulik, 2005).

From a historical perspective, the cultural norm placing a positive moral value on doing a good job because work has intrinsic value for its own sake was a relatively recent development (Lipset, 1990). Work, for much of the ancient history of the human race, has been hard and degrading. Working hard-in the absence of compulsion - was not the norm for Hebrew, classical, or medieval cultures (Rose, 1985). It was not until the Protestant Reformation that physical labour became culturally acceptable for all persons, even the wealthy.

Concept "Ethics" has its background from ancient Greek word "Ethos". At the beginning this word meant a usual place of living (in the poems of Homer), later it acquired new meanings: "habits, temperament, custom, character" (Fassin, 2005).

The work ethics is a cultural norm that places a positive moral value on doing a good job and is based on a belief that work has intrinsic value for its own sake (Cherrington, 1980; Quinn, 1983; Yankelovich, Immerwahr, 1984). Like other cultural norms, a person's adherence to or belief in the work ethics is principally influenced by socialization experiences during childhood and adolescence. Through interaction with family, peers, and significant adults, a person "learns to place a value on work behaviour as others approach him/her in situations demanding increasing responsibility for productivity" (Braude, 1975). Based on praise or blame and affection or anger, a child appraises his or her performance in household chores, or later in part-time jobs, but this appraisal is based on the perspective of others.

Another significant factor shaping the work attitudes of people is the socialization which occurs in the workplace. As a person enters the workplace, the perceptions and reactions of others tend to confirm or contradict the work attitudes shaped in childhood (Braude, 1975). The occupational culture, especially the influence of an "inner fraternity" of colleagues, has a significant impact on the attitudes toward work and the work ethics which form part of each person's belief system.

According to some researchers (Fodor, 1990; Randall, Core, 1991), work ethics can induce employees to be highly involved in their jobs.

K. Ahmad (1976) argues that the Islamic work ethics stands not for life denial but for life fulfilment and holds business motives in the highest regard. Consequently, it is more likely that those who believe in Islam and practice it tend to be more committed to their organizations and presumably more satisfied with their jobs. 
Work ethics- of whatever variety- involves the ascription of value to work. Work is valued as the means to some end ${ }^{1}$. And, being bound up with the attainment of some state of affairs which is valued, people are motivated to work (Gay, Pryke, 2007).

Besides work ethics, another important thing that comes under consideration which influences organizational commitment is organizational culture. In today organization environment, corporate culture is used as powerful tools to quantify the way a business functions (Gray et al., 2003).

The work ethics, as we know today, is a secularized construct derived from Max Weber which is written in his writing more than 100 years ago. Protestant work ethics has been widely used as an explanation for the successful of capitalism in Western (Hill, Lynn, 2009), even though Islam has emerged globally but Muslim societies are very much influenced by Western work ethics, and Malaysia is not exceptional.

Ethics is not simply a glorified intellectual game of no practical relevance. We become moral individuals, as Aristotle says, by practice; good at being truthful by habitually telling the truth; becoming characteristically honest by trying always not to be dishonest (Vallance, 2001).

Ethics is a matter of science, validating moral issues rising between human being and surroundings, in the mutual relations of human beings, among people related by various connections (Gudas, 2000; Kučinskas, 2003 a, b).

Lithuanian authors present various descriptions of ethics. G. Beržinskas (2002) describes the ethics as a philosophy of morality, theory, the human activity which purpose in internal perfection of the personality.

In the book "Verslo etika (Business ethics)", D. Vyšniauskienè (1999) provides the following notion of ethics: Ethics is practical philosophy talking about human behaviour in practical activity. V. Kučinskas (2003 a, b) defines the ethics as a subject of science, validating moral issues, rising between human being and their surroundings, mutual human relations and relations among human beings related to each other by various connections; it is a branch of philosophy analysing values and evaluating human acts.

Culture is the environment that surrounds you at work all the time. Culture is a powerful element that shapes your work enjoyment, your work relationships, and your work processes. But, culture is something that you cannot actually see, except through its physical manifestations in your work place (Heathfield, 2010).

An organization's culture is made up of all of the life experiences each employee brings to the organization. Culture is especially influenced by the organization's founder, executives, and other managerial staff because of their role in decision making and strategic direction (Heathfield, 2010).

In order to disclose the importance of ethics and working culture of the employees we have chosen municipality of Klaipeda region ${ }^{2}$ for the research. Empirical research survey was performed in order to find out the ethical and working culture problems of the employees of public sector,

\footnotetext{
${ }^{1}$ Including the possibilities that work itself serves as the end or that work is not valued per se.

${ }^{2}$ The questionnaires were distributed between employees of public sector, Klaipeda regional municipality.
} 
municipality of Klaipeda region, when the employees were interviewed. The period of the research was January - March 2013. We investigated 85 employees working in Klaipedda municipality.

After the analysis of the empirical research data it can be stated that $63 \%$ of the respondents are familiar with legal regulations regulating ethics of the employees and working culture, $18 \%-$ partly and $19 \%$ are unfamiliar.

When asked how they understood ethics, most of the respondents $-72 \%$ answered that ethics was a science about the norms of behaviour, morality; $14 \%$ stated that this was science researching morality and virtue.

Even $85 \%$ of the interviewed stated that they were following special rules of ethics and working culture in their job, $15 \%$ did not know anything about such rules.

In Fig. 1 we can see the spread of the opinions of the employees concerning what the professional should follow when performing his job.

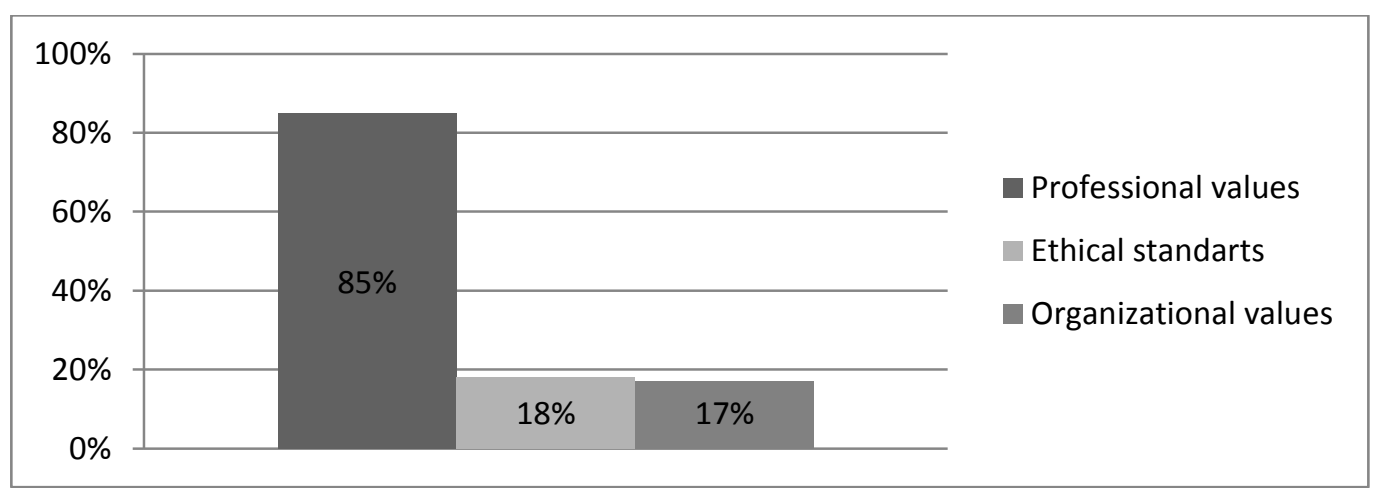

Fig. 1 Spread of the answers of the respondents what the employee should follow when performing their job

$65 \%$ of the interviewed think that they should follow professional values and standards, $18 \%$ - ethical standards, $17 \%$ - organizational values. It shows that professional and organizational values are more important for the employees of public sector than personal ones. This is a good sign because that is the difference of the professionals in public sector from the professionals in private sector.

The opinions were spread more or less equally concerning the question which principle of public service is hardest to implement. It can be seen in Fig. 2.

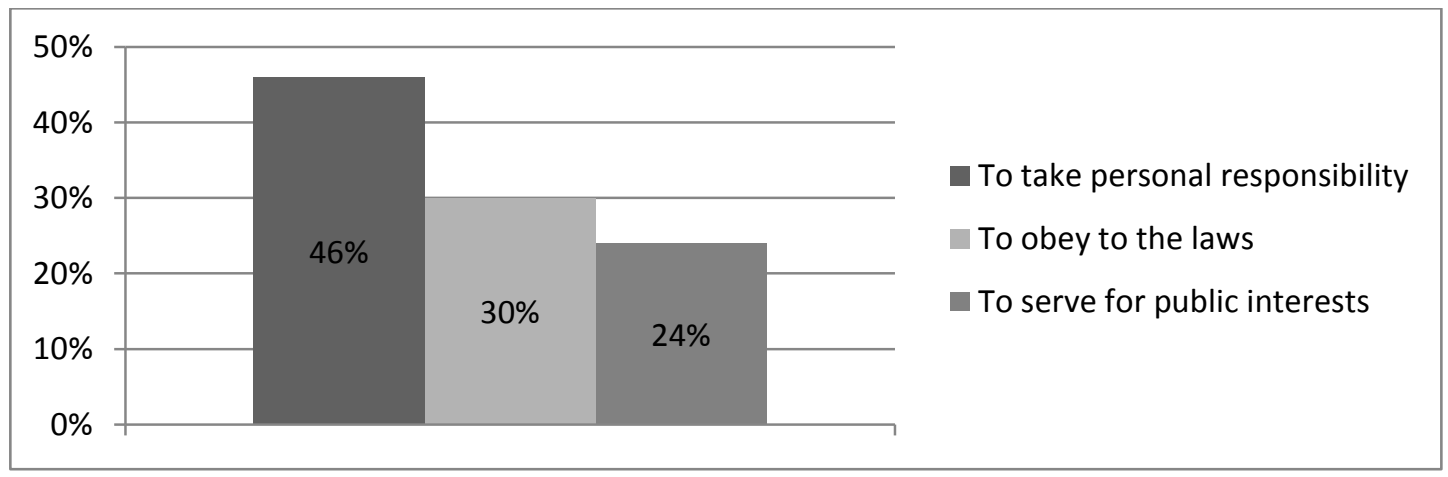

Fig. 2 Spread of the answers of the respondents which principle of public sector is the hardest to implement. 
The hardest is to take personal responsibility for $46 \%$ of the respondents, it is hard to obey to the laws and implement them for $30 \%$ of the employees. As one of the employees has mentioned it is the hardest part to obey to the laws because laws are changing constantly, and sometimes they are really very confusing, complicated and absurd; $24 \%$ of the interviewed stated that the hardest thing is to serve for public interests.

It is thought that the activity of the employees in public sector should be honest. It means that it should be fair, open, correspond to the existing norms of behaviour and always increase the welfare of people. However, sometimes under certain circumstances the situation requires not to be completely open and tell the truth because of completely understandable good intentions or precautions. Sometimes the circumstances make us say that the silence is best thing, sometimes it is thought that "the truth should be used economically"; sometimes it is better to lie or to confuse.

Most of respondents negatively evaluate giving or accepting gifts, or grafts because they treat it as a beginning of corruption (66\%), attempt to bribe, to gain the employee to the side (34\%).

When asked what a gift is for the job done $80 \%$ of the respondents answered that it was flowers, the others mentioned candies, verbal or written thanks, special literature helping to perform the job better, souvenirs.

All employees who participated in the survey confirmed with one accord that they treated money as graft, most some other material values; the others mentioned drinks, souvenirs, candies.

The research helped to disclose the ethical and working culture problems of the employees of Klaipeda municipality; to find out their point of view on the ethical problems, their actions when facing one or another kind of problem.

\section{CONCLUSIONS}

1. Organizations are unlikely to have just a single overarching culture. Instead, multiple cultures or subcultures are often present. Organizational cultures are shared experiences resulting from both low-and high profile successes and failures, patterns of conduct, and self-regulating practices.

2. Ethics and working culture in the work of public sector is nonetheless important than in the work of other professions because they have to communicate with people every day.

3. Work culture change is a process of give and take by all members of an organization. Formalizing strategic direction, systems development, and establishing measurements must be owned by the group responsible for them.

4. Conflicts in the work of public sector are the negative appearance, because of their negative impact on the person itself and the people around - customers, colleagues. It has negative impact on the efficiency of work, communication, working atmosphere.

5. The employees of Klaipeda municipality who participated in the survey agreed with the opinion that the standards of ethics applicable to the public officers are stricter than those applied to ordinary citizens and also the proper image of the employee helps to support public confidence in service. 
6. After separate evaluation how men and women stuck with ethical problems it appeared that men stuck with ethical problems quite rarely $(66 \%)$, women stuck with ethical problems very often $(27 \%)$, or quite often $(27 \%)$. Employees who have been working at public sector for 10 or more years stuck ethical problems more often as well. The salary and education had no influence.

\section{REFERENCES}

1. Ahmad, K. (1976). Islam: Its Meaning and Message, Islamic Council of Europe. London.

2. Beržinskas, G. (2002) Ethics in the Life and Business. Vilnius.

3. Braude, L. (1975). Work and Workers, New York: Praeger.

4. Cherrington, D. J. (1980). The Work Ethic: Working Values and Values That Work, New York: AMACOM.

5. Chen, S. (2005). A Social Exchange Perspective on Business Ethics: An Application to Knowledge Exchange. Journal of Business Ethics, 62, 23-30.

6. Fassin, Y. (2005). The Reasons behind Non-ethical Behaviour in Business and Entrepreneurship. Journal of Business Ethics, 60, 53-63.

7. Fodor, J. (1990). A Theory of Content and Other Essays. Cambridge, MA: MIT Press.

8. Gay, P., Pryke, M. (2007). Cultural Economy. Great Britain: Athenaeum press, Gates head.

9. Gray, J. H., Densten, I. L., Sarros, J. C. (2003). A matter of size: Does organizational culture predict satisfaction in small organizations. Melbourne, Australia: Working paper 65/03, September, Faculty of Business and Economics. Monash University.

10. Gudas, S. (2000). Modelling Organization Activity, Kaunas: Technologija.

11. Heathfield, S. M. (2010). What is organizational culture? Internet link: http://humanresources.about.com/od/organizationalculture/a/culture.htm, [Acessed 201401 15].

12. Hill C., J., Lynn, E. (2009). Public Management: a Three-Dimensional Approach, Wasington, pp. 374.

13. Kučinskas, V. (2003 a). Ethics of the Leader, Klaipeda.

14. Kučinskas, V. (2003 b). Ethics of leadership, Klaipèda.

15. Kulik, B. W. (2005). Agency theory, reasoning and culture at enron: in search of a solution. Journal of Business Ethics, 59, 347-360.

16. Lipset S. M. (1990). The work ethic - then and now. Public Interest, Winter, pp. 61-69.

17. LR Civilinis kodeksas (Civil code). (2001). Kaunas: Poligrafija ir informatika.

18. LR Valstybės tarnybos įstatymas (Law of Lithuania Republic Public Service). (2002). Valstybès žinios, 45 (in Lithuanian).

19. LR Vyriausybès nutarimas Dèl valstybès tarnautojų veiklos etikos taisyklių patvirtinimo ir kt. [For civil servants ethics rules for approval and so on]. (2002). Valstybès žinios. 65 (in Lithuanian).

20. Palidauskaitè, J. (2001) Ethics of Public Administration, Kaunas: Technologija.

21. Perkumienè, D., Raupelienè, A. (2008). Ethics and working culture of the employees in public sector VDU. Organizaciju vadyba: sisteminiai tyrimai, 46, 99-117.

22. Quinn, R. E., Rohrbaugh, J. (1983). A spatial model of effectiveness criteria: Towards a competing values approach to organizational analysis. Management Science, 29, 363-377.

23. Raipa, A. (2001) Viešasis Administravimas [Public Administration], Kaunas: Technologija. (in Lithuanian).

24. Randall, D., Core, J. (1991). Interrelationships of Work Commitment Constructs. Work and Occupations. 18(2), 194-211. 
25. Rose, M. (1985). Reworking the Work Ethic: Economic Values and Socio-Cultural Politics. London: Schocken.

26. Vallance, E. (2001). Business Ethics at Work, Great Britain, Cambridge University press.

27. Vasiljevienè, N. (2000). Verslo Etika ir Etikos Kodeksai [Business Ethics and Codes Of Behavior]. Kaunas (in Lithuanian).

28. Vyšniauskienė, D., Kundrotas, V. (1999). Verslo Etika [Businesh Ethics], Kaunas: Technologija. (in Lithuanian).

29. Wagner-Tsukamoto, S. (2005). An economic approach to business ethics: Moral agency of the firm and the enabling and constraining effects of economic institutions and interactions in a market economy, Journal of Business Ethics, 60, 351-366.

30. Yankelovich, D., Immerwahr, J. (1984). Putting the work ethic to work. Society, 21(2), 58-76.

\title{
ETHICS AND WORKING CULTURE OF THE EMPLOYEES IN THE REGIONAL MUNICIPALITY
}

\author{
Dalia Perkumienè ${ }^{1}$, Rasa Merkienè ${ }^{1}$, Biruta Švagždienè ${ }^{2}$ \\ Aleksandras Stulginskis University ${ }^{l}$, Kaunas, Lithuania \\ Lithuanian Sports University ${ }^{2}$, Kaunas, Lithuania
}

\begin{abstract}
Research background. Ethics covers various areas of life: personal, public and professional relations. Personal ethics studies the well-being of certain individual and their development methods. Social ethics emphasizes well-being of society, duties of individual persons in the society. In the professional ethics the main attention is paid to the behaviour of the representatives of a special field (Raipa, 2001). Employees working in public sector inevitably stick with ethic and working culture problems. Perhaps even more often than the representatives of other fields because they constantly communicate with people, help them to solve their problems every day, inform people about new products (Wagner-Tsukamoto, 2005). When having some contact with employees, people judge the morality and working culture of higher officers and the whole sector according to their behaviour (Chen, 2005). Therefore ethics and working culture of public sector employees should be as high as possible. Ethics is important not only in communication with customers (external environment), it is also important internally in the organization, in the mutual relations between colleagues and staff members (Palidauskaite, 2001). Ethical problems might cause different consequences. Some of them are solved almost unnoticed; the others have strong impact on persons or organizations. Ethical problems might occur and disappear or have a continuous character.
\end{abstract}

The purpose of the work was to disclose the importance of ethics and working culture of the employees in the Klaipeda municipality sector. Object of the work was ethics and working culture of the employees.

Methods. In this paper we used analysis of scientific literature, analysis of legislation, questionnaire survey, statistical analysis of the data, graphical modelling, specifying and summarizing, and logical abstraction methods. We also analysed scientific and practical materials of national and foreign authors (Raipa, 2001; Palidauskaite, 2001; Chen, 2005; Fassin, 2005). In 
order to disclose the importance of ethics and working culture of the employees we chose municipality of Klaipeda region for the research.

Conclusions. Organizations are unlikely to have just a single overarching culture. Instead, multiple cultures or subcultures are often present. Organizational cultures are shared experiences resulting from both low-and high profile successes and failures, patterns of conduct, and selfregulating practices. Ethics and working culture in the work of public sector are nonetheless important than in the work of other professions because they have to communicate with people every day. Work culture change is a process of giving and taking by all members of an organization. Formalizing strategic direction, systems development, and establishing measurements must be owned by the group responsible for them. Conflicts in the work of public sector are the negative appearance because of their negative impact on the person itself and the people around customers, colleagues. It has a negative impact on the efficiency of work, communication, working atmosphere. The employees of Klaipeda municipality who participated in the survey agreed with the opinion that the standards of ethics applicable to the public officers are stricter than those applied to ordinary citizens and also the proper image of the employee helps to support public confidence in service.

Keywords: working culture, ethics, employees, public sector. 